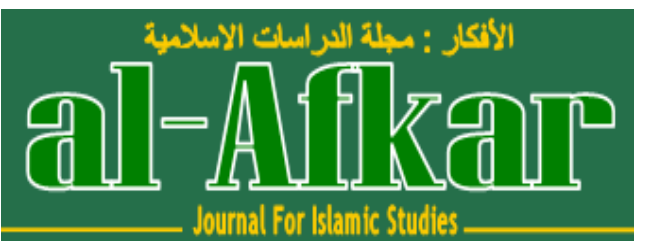

Vol. 3, No. 2, July 2020

P-ISSN : 2614-4883; E-ISSN : 2614-4905

https://al-afkar.com/index.php/Afkar_Journal/issue/view/4

DOI:

\title{
ASWAJA Ke-NUan-BASED ISLAMIC MODERATE EDUCATION AS A RADICALISM STRATEGY
}

\author{
Ari Kartiko \\ Institut Pesantren KH Abdul Chalim Mojokerto \\ E-mail: ari.kartiko5@gmail.com \\ Muhammad Mujtaba Mitra Zuana \\ Institut Pesantren KH Abdul Chalim Mojokerto \\ E-mail: mujtaba.mitrazuana@gmail.com
}

Akhmad Sirojuddin

Institut Pesantren KH Abdul Chalim Mojokerto

E-mail: Akhmadsirojuddin86@gmail.com

Muhammad Anas Ma'arif

Institut Pesantren KH Abdul Chalim Mojokerto

E-mail: anasdt16@gmail.com

\begin{tabular}{|c|c|c|}
\hline Received & Revised & Accepted \\
\hline 3 Maret 2020 & 20 April 2020 & 30 Mei 2020 \\
\hline
\end{tabular}

\section{ASWAJA Ke-NUan-BASED ISLAMIC MODERATE EDUCATION AS A RADICALISM STRATEGY}

\begin{abstract}
This study aims to rationalize the Aswaja-based Islamic education strategy to counter radicalism. This research method uses literature by analyzing published, unpublished books, journals and research that are in line with the theme of moderate Islamic education through NU-an Aswaja. The results of this study are that NU implements an educational education commanded by LP Maarif NU and principled on al muhafadhotu ala al qodimi as sholih wal akhdu bil jadidi al aslah to aim at forming humans who are rahmatan lin naturalin. In learning the values that are strengthened and internalized are tawazun (balanced), tawassuh (moderate), i'tidal (fair and heartless) and tasammuh (tolerance).
\end{abstract}

Keywords: Aswaja, Moderate, and multiculturalism. 


\title{
Ari Kartiko et al
}

Aswaja Ke-NU-an Based Islamic......

\begin{abstract}
Abstrak
Kajian ini bertujuan merasionalisasi strategi pendidikan Islam berbasis Aswaja untuk melawan radikalisme. Metode penelitian ini menggunakan studi pustaka dengan cara menganalisis buku, jurnal, dan penelitian yang diterbitkan dan tidak diterbitkan yang sesuai dengan tema pendidikan Islam moderat melalui NU-an Aswaja. Hasil penelitian ini adalah NU melaksanakan pendidikan pendidikan yang dipimpin oleh LP Maarif NU dan berprinsip pada al muhafadhotu ala al qodimi sebagai sholih wal akhdu bil jadidi al aslah dengan tujuan membentuk manusia yang rahmatan lin naturalin. Dalam pembelajaran nilai-nilai yang dikuatkan dan diinternalisasikan adalah tawazun (seimbang), tawassuh (moderat), i`tidal (adil dan tidak berperasaan) dan tasammuh (toleransi).
\end{abstract}

Kata kunci: aswaja, moderat, dan multikulturalisme.

\section{Introduction}

Radicalism is a rising phenomenon in recent times ${ }^{1}$. We can see it because of the formation of religious organizations that carry out their mission with violence ${ }^{2}$. Radical Islamic organizations have a variety of characteristics, variants and orientations ${ }^{3}$. But radical Islamic organizations have in common, which is to choose the path of violence. Radical Islam grew massively on the responses from various diverse parties. There are those who give positive responses as supporters, reactiveemotional, creative and even anarchist ${ }^{4}$. However, the response of the radical Islamic movement cannot be dammed or stopped. In fact the number of members of radical Islamic organizations is increasing 5 .

Indonesian Islam is famous for its friendly, tolerant and humanist character ${ }^{6}$. With the existence of radical Islamic organizations it can be a threat to the future of Indonesian Islam itself7. Where is Indonesian Islam which has lived for decades in peace and peace because of tolerance. Radical Islam will not be able to live in the

${ }^{1}$ Abdallah Abdallah, 'Exclusivism and Radicalism in Schools: State Policy and Educational Politics Revisited', Studia Islamika 23, no. 3 (30 December 2016): 625-32, https://doi.org/10.15408/sdi.v23i3.4425; Syamsul Arifin, 'Islamic Religious Education and Radicalism in Indonesia: Strategy of de-Radicalization through Strengthening the Living Values Education', Indonesian Journal of Islam and Muslim Societies 6, no. 1 (1 June 2016): 93, https://doi.org/10.18326/ijims.v6i1.93-126.

2 Muhammad Thohir, 'Radikalisme Versus Pendidikan Agama Menggali Akar Radikalisme Dari Kekerasan Terhadap Anak Atas Nama Pendidikan Agama', Nadwa 9, no. 2 (2015): 167-182.

3 Muhammad Nida' Fadlan and Rangga Eka Saputra, 'Islam, Radicalism, Democracy, and Global Trends in Southeast Asia', Studia Islamika 24, no. 3 (31 December 2017): 643-47, https://doi.org/10.15408/sdi.v24i3.6566.

4 Syamsul Ma'arif, 'Ideologi Pesantren Salaf: Deradikalisasi Agama Dan Budaya Damai', Ibda' 12, no. 2 (2014): 198-209.

5 Tiyas Nur Haryani et al., 'Islamic Education in Supporting De-Radicalization: A Review of Islamic Education in Pondok Pesantren', Nadwa 12, no. 2 (7 January 2019): 259-72, https://doi.org/10.21580/nw.2018.12.2.2581.

${ }^{6}$ Amy L. Freedman, 'Civil Society, Moderate Islam, and Politics in Indonesia and Malaysia', Journal of Civil Society 5, no. 2 (2009): 107-127.

${ }^{7}$ Alexander Raymond Arifianto, 'Islam Nusantara: NU's Bid to Promote "Moderate Indonesian Islam", 2016, https://dr.ntu.edu.sg/handle/10220/40704. 
future because of the disclaimer of the wisdom of Indonesian cultural values. From the violence that they take that continues to grow will make it difficult for us to find a peaceful and tolerant life ${ }^{8}$.

Therefore, mainstream Islamic organizations so that the influence of radical Islam does not stick, it is very necessary active-creative and constructive response. Radical Islam massively conducted a network of young people ${ }^{9}$. This is necessary because generally they do not have mature experience of religion ${ }^{10}$. They are easily indoctrinated with certain ideologies so that they are ready to struggle to carry out the organization's vision and mission with any compensation. With many young people converting to radical Islam, various parties have intervened to anticipate the seeds of radicalism. The increasingly widespread radical Islam can reduce the multicultural social harmony of Indonesian society ${ }^{11}$.

One of the prevention of the development of radical Islam is learning delivered by teachers in classes in a structured and systematic manner that allows students to know and understand and can apply the knowledge gained so as to understand the problem wisely. Through learning students are expected to understand what is radical Islam, its characteristics and the dangers and aspects related to radical Islam comprehensively. Among the lessons that can prevent radicalization are Aswaja's lessons.

As consideration and reference to continue this research, Muhammad Anas $2018^{12}$ research that NU campus in Malang implements tolerance in conducting multicultural education with multicultural knowing, multicultural feeling and

\footnotetext{
${ }^{8}$ Riza Istanto and T. Triyanto, 'Religious Tolerance Through Stone Sculpture Production: The Case of Indonesian Sculptors', Walisongo: Jurnal Penelitian Sosial Keagamaan 27, no. 1 (30 July 2019), https://doi.org/10.21580/ws.27.1.3630.

${ }_{9}$ Dirga Maulana, 'The Exclusivism of Religion Teachers: Intolerance and Radicalism in Indonesian Public Schools', Studia Islamika 24, no. 2 (31 August 2017): 395-401, https://doi.org/10.15408/sdi.v24i2.5707.

10 Choirul Mahfud et al., 'Religious Radicalism, Global Terrorism and Islamic Challenges in Contemporary Indonesia', Jurnal Sosial Humaniora 11, no. 1 (27 July 2018): 8-18-18, https://doi.org/10.12962/j24433527.v11i1.3550; Abdurrohman Abdurrohman and Huldiya Syamsiar, 'Pembelajaran Pendidikan Agama Islam (PAI) Model Keberagamaan Inklusif Untuk Mencegah Radikalisme Beragama Dikalangan Siswa SMA', FENOMENA 9, no. 1 (1 June 2017): 105-22, https://doi.org/10.21093/fj.v9i1.789.

11 Achmad Asrori, 'Contemporary Religious Education Model on the Challenge of Indonesian Multiculturalism', JOURNAL OF INDONESIAN ISLAM 10, no. 2 (1 December 2016): 261-84, https://doi.org/10.15642/JIIS.2016.10.2.261-284; Lusia Mumtahanah, 'Integrasi Nilai Multikultural Dalam Pembelajaran Pendidikan Agama Islam Di Sekolah Dasar', Nazhruna: Jurnal Pendidikan Islam 3, no. 1 (7 February 2020): 55-74, https://doi.org/10.31538/nzh.v3i1.461; Muhammad Dachlan, Nur Laili Noviani, and Mustolehudin Mustolehudin, 'Building Harmony Through Religious Counseling (The Religious Harmony Portrait in North Mamuju)', Esensia: Jurnal Ilmu-Ilmu Ushuluddin 19, no. 1 (22 May 2018): 117-28, https://doi.org/10.14421/esensia.v19i1.1491.

${ }^{12}$ Muhammad Anas Ma`arif, 'Internalisasi Nilai Multikulutural Dalam Mengembangkan Sikap Toleransi ( Studi Di Di Pesantren Mahasiswa Universitas Islam Malang)', Nazhruna: Jurnal Pendidikan Islam 2, no. 1 (24 March 2019), https://doi.org/10.31538/nzh.v2i1.179.
} 
multicultural action in student day activities, student freshmen, study activities and social interaction. Toto Suharto $2015^{13}$ produced research that NU as an organization that implements moderate attitudes through education by applying the values of tasamuh, tawazun, i'tidal and tawassuth. The research was also strengthened by Fauzan's research in $2019^{14}$. From the results of these studies, the authors were interested in researching the literature on moderate Islamic education strategies based on Aswaja to the NU.

\section{Islamic Perspective of Radicalism}

Radical words come from the Latin "radix" which means root. In English the word radical can mean extreme, comprehensive, fanatical, revolutionary, ultra and fundamental ${ }^{15}$. While radicalism means the doctrine or practice of adherents to radicalism or extreme understanding ${ }^{16}$. In the Big Indonesian Dictionary, radicalism is defined as "understanding or flow that wants change in a hard or drastic way. While Sartono Kartodirdjo defines radicalism as "a social movement which rejects the overall ongoing social order and is characterized by strong moral irritation to oppose and hostile to people who have special rights and power"17. Thus it can be concluded that radicalism is a symptom of a society that can occur in general with a variety of motives, such as political, social, cultural and religious, which is characterized by various extreme, violent and anarchic actions as a form of rejection of the symptoms or problems that are being faced.

Religious radicalism (Islam) can be defined as understandings and values of religious teachings (Islam) that are implemented in a hard, fanatical, and extreme and fundamental way ${ }^{18}$. But not all acts of violence that are anarchist in nature stem from religious radicalism. Indeed, in reality we can find several groups of radical religious movements that are only limited to ideology and thought, and do not use violence in carrying out its mission, but there are also radical groups in carrying out

13 Toto Suharto, 'Gagasan Pendidikan Muhammadiyah dan NU sebagai Potret Pendidikan Islam Moderat di Indonesia', Islamica: jurnal studi keislaman 9, no. 1 (23 September 2015): 81-109, https://doi.org/10.15642/islamica.2014.9.1.81-109.

${ }^{14}$ Subandi Subandi et al., 'Implementation of Multicultural and Moderate Islamic Education at the Elementary Schools in Shaping the Nationalism', Tadris: Jurnal Keguruan Dan Ilmu Tarbiyah 4, no. 2 (27 December 2019): 247-55, https://doi.org/10.24042/tadris.v4i2.5003.

${ }^{15}$ Rahimi Sabirin, Islam \& radikalisme (Jakarta: Teras, 2004).

${ }^{16}$ Syahrin Harahap, Upaya kolektif mencegah radikalisme \& terorisme [sumber elektronis] (Prenada Media, 2017).

${ }^{17}$ Sartono Kartodirdjo, Sejak Indische sampai Indonesia (Penerbit Buku Kompas, 2005).

18 Nur Syam, Tantangan Multikulturalisme Indonesia: Dari Radikalisme Menuju Kebangsaan (Yogyakarta, Indonesia: Penerbit Kanisius, 2009). 
their religious ideology by justifying violent means. Therefore, religious radicalism is not always marked by anarchism or terrorism ${ }^{19}$.

Rubaidi explained that the characteristics of the Islamic radicalism movement were divided into five parts, namely: First, a person in regulating the social, religious and political life of the state used Islamic ideology. Secondly, without considering the socio-political situation, they adopt the source of Islamic values from the Middle East as they are without thought and translated according to context. Third, they are more focused on the text of the Qur'an and the Hadith or also called understanding the Qur'an textually. Fourth, do not accept ideologies other than Islam from the Middle East, such as liberalism, secularism, and democracy. Fifth, one feels less compatible with the movement of moderate Islamic groups both towards the community and the government ${ }^{20}$.

Radicalism in religion is like a double-edged knife, on the one hand, the positive meaning of radicalism is the spirit towards change for the better which is commonly called ishlah (improvement) or tajdid (renewal). Thus radicalism is not a synonym of extremism or violence, it will be very meaningful if it is carried out through a thorough understanding of religion and is applied to the personal sphere. But on the other hand, radicalism will become dangerous if it reaches the level of ghuluw (over the limit) and ifrath (outrageous) when forced upon followers of other religions $^{21}$. According to Madjid that Islam is a religion of peace that teaches an attitude of peace and the search for peace ${ }^{22}$. Islam has never justified the practice of using violence in spreading religion, religious understanding and political understanding. But it is undeniable that in the course of its history there are certain Islamic groups who use the path of violence to achieve political goals or maintain a rigid religious understanding which in the language of global civilization is often called Islamic radicalism ${ }^{23}$.

The Koran forbids one to commit violence and anti-social. However, if a verse is found about radicalism, it is actually blocked by the maqasid Qur' an. If a person is allowed to kill and fight, all of them must be based on protecting themselves (life) hifdzun nafs, guarding religion haifdzu ad din, protecting property hifzhu al maal

19 Emna Laisa, 'Islam Dan Radikalisme', Islamuna: Jurnal Studi Islam 1, no. 1 (2 January 2014), https://doi.org/10.19105/islamuna.v1i1.554.

${ }^{20}$ A. Rubaidi, Radikalisme Islam, Nahdlatul Ulama \& masa depan moderatisme Islam di Indonesia (Logung Pustaka, 2008).

${ }^{21}$ Azyumardi Azra, 'Distinguishing Indonesian Islam: Some Lessons to Learn', Islam in Indonesia: Contrasting Images and Interpretations, 2013, 63-74; Laisa, 'Islam Dan Radikalisme'.

${ }^{22}$ Nur Achmad and Nucholis Madjid, Pluralitas agama: kerukunan dalam keragaman (Kompas Media Nusantara, 2001); Sun c Ummah, 'Akar Radikalisme Islam Di Indonesia', HUMANIKA 12, no. 1 (2012).

${ }^{23}$ Harun Nasution, Islam ditinjau dari berbagai aspeknya. Jilid II: ..., Cet. 6 (Jakarta: Penerbit Universitas Indonesia, 1986). 
and guarding their minds hifzhu al $a \mathrm{ql}^{24}$. Adherents of radicalism have a perspective that is sharia is an absolute thing that must be upheld in public life through coercion of people or groups. The road they took began by combating disobedience using the path of violence without regard to applicable law. ${ }^{25}$

\section{Education-Based Deradicalization}

Most people assume that radical Islam is a threat to religious harmony. Radical Islam acts violently to carry out its mission in the form of systemic violence, actual violence or symbolic violence which makes radical Islam a terrifying mental terror for mankind, especially for Islamic groups themselves. Radical Islamic groups have a deeply ingrained character that their religious understanding is an absolute truth. From these beliefs that cause no constructive dialogue space to discuss issues in life ${ }^{26}$.

Radical Islam in Indonesia has developed rapidly, this is a significant challenge for the life of religious people and the country ${ }^{27}$. Indonesia is a country with pluralistic characteristics, even the most plural society ${ }^{28}$. Therefore it is not excessive if Indonesia is declared as a multi-ethnic, multi-faith, and multi-cultural political expression ${ }^{29}$. This diversity owned by Indonesia must be managed optimally, well, honestly and smartly so that it can be made a great cultural wealth. Such great wealth could be destroyed by the violence of radical Islamic groups. Radical Islam finds it difficult to accept ideas even if they are from outside groups ${ }^{30}$.

The ideas they bring are not to be debated or discussed, but rather to be accepted and implemented absolutely. If a person or group does not accept it, they will find other ways so that other groups can accept it. This group often uses the word "Kafir" as an expression that anyone who is not in accordance with the

${ }^{24}$ Ulya Fikriyati, 'Maqâsid al-Qur'ân dan Deradikalisasi Penafsiran dalam Konteks Keindonesiaan', ISLAMICA: Jurnal Studi Keislaman 9, no. $1 \quad$ (23 September 2015): 244-67, https://doi.org/10.15642/islamica.2014.9.1.244-267.

${ }^{25}$ Laisa, 'Islam Dan Radikalisme', 11.

${ }^{26}$ Husniyatus Salamah Zainiyati, 'Curriculum, Islamic Understanding and Radical Islamic Movements in Indonesia', Journal of Indonesian Islam 10, no. 2 (2016): 285-307, https://doi.org/10.15642/JIIS.2016.10.2.285-308; Muzayyin Ahyar, 'Membaca Gerakan Islam Radikal Dan Deradikalisasi Gerakan Islam', Walisongo: Jurnal Penelitian Sosial Keagamaan 23, no. 1 (15 June 2015): 126, https://doi.org/10.21580/ws.23.1.220.

${ }^{27}$ Abdurrahman Wahid, Islamku Islam Anda Islam Kita: Agama Masyarakat Negara Demokrasi (Jakarta Pusat: The Wahid Institute, 2006), https://archive.org/details/abdurrahmanwahid-islamkuislamandaislamkita2006.

${ }^{28}$ Alexander R. Arifianto, 'Practicing What It Preaches? Understanding the Contradictions between Pluralist Theology and Religious Intolerance within Indonesia's Nahdlatul Ulama', Al-Jami 'ah: Journal of Islamic Studies 55, no. 2 (15 December 2017): 241-64, https://doi.org/10.14421/ajis.2017.552.241-264.

${ }^{29}$ Raihani, Creating Multicultural Citizens: A Portrayal of Contemporary Indonesian Education, 2014, http://search.ebscohost.com/login.aspx?direct=true\&scope=site\&db=nlebk\&db=nlabk\&AN=664169.

30 Anthony Reid, 'Religious Pluralism or Conformity in Southeast Asia's Cultural Legacy', Studia Islamika 22, no. 3 (2015): 387-404, http://journal.uinjkt.ac.id/studia-islamika/article/view/2352. 
teachings they believe and they believe in. They easily swear at unbelievers to fellow Muslims if they are not in accordance with their nets and even moderate NU and Muhammadiyah followers are branded as such ${ }^{31}$. According to their assumption that infidels must be fought to death or follow the teachings of radicalism. Radical Islam justifies the use of any path against those who disagree with their opinions, including the path of violence or terrorism ${ }^{32}$.

Radical Islamic groups have a vision of refining Islamic teachings. According to Kato, "is a mere fantasy of religious purification carried out by radical Islamic groups". Because the real interpretation and relative purification that they glorify. Such claims are not the most good and true. Factors that influence interpretation include social, cultural, political, and education. Those are some of the reasons why the claims for purification of religion cannot be justified.

Education is a medium that is quite effective in stemming the flow of radical Islam. Because comprehensive is a progress that can be achieved by humans ${ }^{33}$. Of high concern for education, it will become a more advanced foothold. Through education someone will have high character, knowledge and expertise. Because it is a necessity for a nation. Education is a future savings socially, intellectually, financially and culturally. With broad insight, experience, knowledge and adequate life skills as well as developing one's potential optimally that can be used as capital in life. In addition to students, the education system is a very determining factor in student success. With maximum effort, it is hoped that it can lift honor and dignity through the birth of educated people and love of culture ${ }^{34}$.

An Islamic educational institution can be categorized as a bearer of moderate Islam, when the parent organization or institution has an ideology of moderate Islam. Conversely, an Islamic educational institution can be categorized as a bearer of radical Islam, when the parent organization or institution has a radical ideology of Islam. From this we need a clear understanding between Islam of moderate ideology

31 Alexander R. Arifianto, 'Islam with Progress: Muhammadiyah and Moderation in Islam', 2017, https://r.ntu.edu.sg/handle/10220/44024; Masdar Hilmy, 'Whither Indonesia's Islamic Moderatism? A Reexamination on the Moderate Vision of Muhammadiyah and Nu', Journal of Indonesian Islam 7, no. 1 (1 June 2013): 24-48, https://doi.org/10.15642/JIIS.2013.7.1.24-48.

${ }^{2}$ Ngainun Naim, 'Pengembangan Pendidikan Aswaja Sebagai Strategi Deradikalisasi', Walisongo: Jurnal Penelitian Sosial Keagamaan 23, no. 1 (15 June 2015): 69-88, https://doi.org/10.21580/ws.23.1.222.

${ }^{33}$ Muhammad Saekan Muchith, 'Radikalisme Dalam Dunia Pendidikan', ADDIN 10, no. 1 (2016): 163180.

34 Zakiya Darajat, 'Muhammadiyah Dan NU: Penjaga Moderatisme Islam Di Indonesia', Hayula: Indonesian Journal of Multidisciplinary Islamic Studies 1, no. 1 (30 January 2017): 79-94, https://doi.org/10.21009/hayula.001.1.05; Toto Suharto, 'Indonesianisasi Islam: Penguatan Islam Moderat Dalam Lembaga Pendidikan Islam Di Indonesia', Al-Tahrir: Jurnal Pemikiran Islam 17, no. 1 (24 May 2017): 155-78, https://doi.org/10.21154/altahrir.v17i1.803. 


\section{Ari Kartiko et al}

Aswaja Ke-NU-an Based Islamic......

and Islam of radical ideology ${ }^{35}$. Islamic moderateism in Indonesia displayed by these two organizations can at least be seen from the religious understanding adopted by Muhammadiyah and NU. In the field of theology, these two organizations claim to be adherents of ah luss unah wal jam a 'ah (aswaja) ${ }^{36}$. As a containment of radicalism, the two organizations vigorously conduct anti-radicalism studies, especially through education. NU internalizes anti-radicalism education by providing $\mathrm{Nu}$-an Aswaja learning at every level of education. as well as Muhammadiyah doing moderate learning with typical Muhammadiyah tajdids ${ }^{37}$.

\section{Aswaja Ke-Nuan Values}

The values contained in Aswaja become significant to be actualized amid the current of radicalism. Aswaja values can be a barrier to radicalism. The reconstruction of Aswaja values through education is expected to be significant to the teachings of moderate Islam. Islam is not always synonymous with violence. The polite and gentle way can make Islam exist and become a part that has fallen from Indonesian life for decades. Aswaja did not receive a response to the settlement of cases by inhumane, violent, coercive, to vandalism.

Al-Qur'an, as-Sunnah, al-Ijma 'and Qiyas are sources of Islamic law in view of the paradigm of Aswaja's thought. Aswaja followed the product of the thought of the salaf scholars in their daily practice ${ }^{38}$. The characteristics of the Aswaja are divided into three pillars, namely in the field of fiqh (jurisprudence) following one of the four Imams of Madhhab (Imam Shafi'i, Imam Hanafi, Imam Maliki and Imam Hambali) and in theology the following Imam al-Asy'ari and al-Maturidi and in the field of Sufism following Imam al-Ghazali and Imam Junaid al-Baghdadi ${ }^{39}$.

The NU organization has values that must be instilled into daily life in order to foster a sense of caring, tolerance and diversity. These values are: 1) Moderate (tawassut) 2) Tawazun (balanced), 3) Tolerance (tasamuh). ${ }^{40}$ These three values in religious life continue to stem radicalism through education has always been the main key. the moderate principle is applied in all fields, including state life, NU has always been "loyal" to the Republic of Indonesia, together with Muhammadiyah,

${ }^{35}$ Suharto, 'Gagasan Pendidikan Muhammadiyah dan NU sebagai Potret Pendidikan Islam Moderat di Indonesia', 87.

${ }^{36}$ Darajat, 'Muhammadiyah Dan NU', 86.

${ }^{37}$ Haedar Nashir et al., 'Muhammadiyah's Moderation Stance in the 2019 General Election: Critical Views from Within', Al-Jami'ah: Journal of Islamic Studies 57, no. 1 (29 June 2019): 1-24, https://doi.org/10.14421/ajis.2019.571.1-24; Darajat, 'Muhammadiyah Dan NU'.

${ }^{38}$ Achmad Shiddiq, Khittah Nahdliyyah (NU) (Surabaya: Khalista-LTN NU Jawa Timur, 2006).

39 Ahmad Ali, 'Aktualisasi Nilai-Nilai Aswaja NU Dalam Mencegah Redikalisme Agama', Jurnal Al Dzikra 5, no. 9 (2014), https://ejournal.radenintan.ac.id/index.php/adzikra/article/view/343.

${ }^{40}$ Suharto, 'Gagasan Pendidikan Muhammadiyah dan NU sebagai Potret Pendidikan Islam Moderat di Indonesia'. 
rejecting the establishment of an Islamic state. Related to this, Mark Woodward for example assesses: "Like Muhammadiyah, NU rejects the concept of an Islamic state, arguing that Islam, as a religion, places greater emphasis on piety than politics". ${ }^{41}$

$\mathrm{KH}$. Achmad Siddiq said that in interpreting the principle of tawassut this is $^{42}$ :

"Tawassut (including i'tidâl and tawâzun) is not all-round compromise by confusing all elements (syncretism). Neither does he exclude himself from refusing to meet with any element. The character of tawassut for Islam is indeed from the very beginning Allah has put in Islam all the goodness, and all the goodness is certainly found between the ends of the tatarruf, endless nature, extremism. The principle and character of tawassut which has become the character of Islam must be applied in all fields, so that the Islamic Religion and the attitudes and behavior of Muslims will always be witnesses and gauges of truth for all attitudes and general human behavior "

Through these principles, NU always takes the position of an accommodative, tolerant attitude and avoids extreme attitudes (tafrîth, ifrâth) in dealing with any cultural spectrum. Because the Aswaja paradigm here reflects the attitude of NU which is always calculated on the basis of legal considerations that lead to aspects of maslaha and mafsadah. These are the values of Aswaja inherent in the body of NU which are the assessment and imaging of Islam rahmatan lil 'alamin in the eyes of the world ${ }^{43}$.

NU's moderate values to stem the flow of radicalism are applied in NU's Maarif Education Institute. LP Maarif NU made guidelines for all institutions under its auspices to always internalize the moderate values of NU, both in learning or in extracurricular activities. Good traditions are always preserved and take on new traditions to develop the value of the goodness and welfare of the Ummah. Ke-Nuan Aswaja learning takes place from elementary school to university level. The implementation of Aswaja Ke-Nuan is applied in everyday life and Indonesian traditional traditions.

\section{Aswaja's Internalization Strategy in Islamic Education}

Forms of radicalism in education are not all in the form of acts of violence, but can also be addressed in the form of words and attitudes that have the potential

${ }^{41}$ Mark R. Woodward and Damardjati Supadjar, Islam Jawa: Kesalehan Normatif versus Kebatinan, Cet. 1 (Yogyakarta: LKiS, 1999).

${ }^{42}$ Achmad Shiddiq, Khittah Nahdliyyah (NU).

${ }^{43}$ Ali, 'Aktualisasi Nilai-Nilai Aswaja NU Dalam Mencegah Redikalisme Agama'. 
to give birth to violence that is not in accordance with educational norms ${ }^{44}$. As an organization that drives Islamic moderation in Indonesia, NU has always been the front guard in the fight against radicalism and religious extremism. This means that NU always teaches all people to act in the middle or wasatiyah attitude. This moderate attitude is important to internalize early on in the life of the community, politicized and religious. Seeing the current condition that radicalism flourishes in the higher education environment and radicalism and extremism due to late and less comprehensive religious experience ${ }^{45}$, NU provides an appropriate strategy for education that provides an early understanding of the education environment by providing Aswaja Nuan lessons at various levels.

Looking at the syllabus that was used in elementary schools, the strategy in instilling NU's moderate stance was:

Tabel of Value Internalization

\begin{tabular}{|c|c|c|}
\hline No & $\begin{array}{c}\text { Stages of } \\
\text { Internalization } \\
\end{array}$ & Description of Activities \\
\hline 1 & Value Transformation & $\begin{array}{l}\text { 1. In learning, introducing a moderate } \\
\text { attitude to religion, politics and society. } \\
\text { 2. Introduce NU's religious attitude and } \\
\text { bermadzhab. } \\
\text { 3. Tells the story of the Aswaja figures of } \\
\text { the Prophet's companions, guardians of } \\
\text { the nine, and NU kyai. }\end{array}$ \\
\hline 2 & Value Transaction & $\begin{array}{l}\text { 1. Take an example of NU figures } \\
\text { 2. The teacher invites students to take part } \\
\text { in tahlilan, yasinan and other local } \\
\text { wisdom activities. }\end{array}$ \\
\hline 3 & Value Internalization & $\begin{array}{l}\text { 1. Students attend IPNU activities } \\
\text { 2. Students follow NU tradition activities } \\
\text { (mauludan, tahlilan and others) }\end{array}$ \\
\hline
\end{tabular}

The most important principle in carrying out learning in the NU education environment is to maintain old values that are still relevant and good and take new values better for the welfare of the Ummah.

${ }^{44}$ Muchith, 'Radikalisme Dalam Dunia Pendidikan', 173.

45 Azyumardi Azra, 'Kesalehan dan Politik: Islam Indonesia', Studia Islamika 25, no. 3 (4 December 2018): 639-50, https://doi.org/10.15408/sdi.v25i3.9993; Liputan6.com, 'Perguruan Tinggi Terpapar Radikalisme', liputan6.com, 5 June 2018, https://www.liputan6.com/news/read/3549087/perguruan-tinggiterpapar-radikalisme; A. Jainuri, Radikalisme dan terorisme: akar ideologi dan tuntutan aksi (Intrans Publishing, 2016). 


\section{Conclussion}

Nahdlatul Ulama applied anti-radicalism strategies in various lines and in this study applied in the world of education with the principle of al muhafadhotu ala al qodimi as sholih wal akhdu bil jadidi al aslah. Applying moderate attitude in the world of education by providing NU scholarship learning with tawassuth, i tidal, tawazzun and tasammuh materials. NU's moderate and societal attitude were instilled in three stages: value transactions, value transformation and value transinternalization. The goal in learning is to form humans who are rahmatan lil alamin and able to practice moderate attitudes. Understanding jihad as a verse is not just a war but rather a jihad to understand religion in its entirety and comprehensively and jihad against oneself.

\section{References}

Abdallah, Abdallah. 'Exclusivism and Radicalism in Schools: State Policy and Educational Politics Revisited'. Studia Islamika 23, no. 3 (30 December 2016): 625-32. https://doi.org/10.15408/sdi.v23i3.4425.

Abdurrohman, Abdurrohman, and Huldiya Syamsiar. 'Pembelajaran Pendidikan Agama Islam (PAI) Model Keberagamaan Inklusif Untuk Mencegah Radikalisme Beragama Dikalangan Siswa SMA'. FENOMENA 9, no. 1 (1 June 2017): 105-22. https://doi.org/10.21093/fj.v9i1.789.

Achmad, Nur, and Nucholis Madjid. Pluralitas agama: kerukunan dalam keragaman. Kompas Media Nusantara, 2001.

Achmad Shiddiq. Khittah Nahdliyyah (NU). Surabaya: Khalista-LTN NU Jawa Timur, 2006.

Ahyar, Muzayyin. 'Membaca Gerakan Islam Radikal Dan Deradikalisasi Gerakan Islam'. Walisongo: Jurnal Penelitian Sosial Keagamaan 23, no. 1 (15 June 2015): 1-26. https://doi.org/10.2158o/ws.23.1.220.

Ali, Ahmad. 'Aktualisasi Nilai-Nilai Aswaja NU Dalam Mencegah Redikalisme Agama'. Jurnal Al Dzikra 5, no. 9 (2014). https://ejournal.radenintan.ac.id/index.php/adzikra/article/view/343.

Arifianto, Alexander R. 'Islam with Progress : Muhammadiyah and Moderation in Islam', 2017. https://dr.ntu.edu.sg/handle/10220/44024.

. 'Practicing What It Preaches? Understanding the Contradictions between Pluralist Theology and Religious Intolerance within Indonesia's Nahdlatul Ulama'. Al-Jami'ah: Journal of Islamic Studies 55, no. 2 (15 December 2017): 241-64. https://doi.org/10.14421/ajis.2017.552.241-264.

Arifianto, Alexander Raymond. 'Islam Nusantara: NU's Bid to Promote "Moderate Indonesian Islam"', 2016. https://dr.ntu.edu.sg/handle/10220/40704.

Arifin, Syamsul. 'Islamic Religious Education and Radicalism in Indonesia: Strategy of de-Radicalization through Strengthening the Living Values Education'. 
Indonesian Journal of Islam and Muslim Societies 6, no. 1 (1 June 2016): 93. https://doi.org/10.18326/ijims.v6i1.93-126.

Asrori, Achmad. 'Contemporary Religious Education Model on the Challenge of Indonesian Multiculturalism'. JOURNAL OF INDONESIAN ISLAM 10, no. 2 (1 December 2016): 261-84. https://doi.org/10.15642/JIIS.2016.10.2.261-284.

Azra, Azyumardi. 'Distinguishing Indonesian Islam: Some Lessons to Learn'. Islam in Indonesia: Contrasting Images and Interpretations, 2013, 63-74.

. 'Kesalehan dan Politik: Islam Indonesia'. Studia Islamika 25, no. 3 (4 December 2018): 639-50. https://doi.org/10.15408/sdi.v25i3.9993.

Dachlan, Muhammad, Nur Laili Noviani, and Mustolehudin Mustolehudin. 'Building Harmony Through Religious Counseling (The Religious Harmony Portrait in North Mamuju)'. Esensia: Jurnal Ilmu-Ilmu Ushuluddin 19, no. 1 (22 May 2018): 117-28. https://doi.org/10.14421/esensia.v19i1.1491.

Darajat, Zakiya. 'Muhammadiyah Dan NU: Penjaga Moderatisme Islam Di Indonesia'. Hayula: Indonesian Journal of Multidisciplinary Islamic Studies 1, no. 1 (30 January 2017): 79-94. https://doi.org/10.21009/hayula.001.1.05.

Fadlan, Muhammad Nida', and Rangga Eka Saputra. 'Islam, Radicalism, Democracy, and Global Trends in Southeast Asia'. Studia Islamika 24, no. 3 (31 December 2017): 643-47. https://doi.org/10.15408/sdi.v24i3.6566.

Fikriyati, Ulya. 'Maqâsid al-Qur'ân dan Deradikalisasi Penafsiran dalam Konteks Keindonesiaan'. ISLAMICA: Jurnal Studi Keislaman 9, no. 1 (23 September 2015): 244-67. https://doi.org/10.15642/islamica.2014.9.1.244-267.

Freedman, Amy L. 'Civil Society, Moderate Islam, and Politics in Indonesia and Malaysia'. Journal of Civil Society 5, no. 2 (2009): 107-127.

Harahap, Syahrin. Upaya kolektif mencegah radikalisme $\mathcal{E}$ terorisme [sumber elektronis]. Prenada Media, 2017.

Haryani, Tiyas Nur, Muhammad Ikhsanul Amin, Nur Hidayatul Arifah, and Arina Mardhiyana Husna. 'Islamic Education in Supporting De-Radicalization: A Review of Islamic Education in Pondok Pesantren'. Nadwa 12, no. 2 (7 January 2019): 259-72. https://doi.org/10.21580/nw.2018.12.2.2581.

Hilmy, Masdar. 'Whither Indonesia's Islamic Moderatism? A Reexamination on the Moderate Vision of Muhammadiyah and Nu'. Journal of Indonesian Islam 7 , no. 1 (1 June 2013): 24-48. https://doi.org/10.15642/JIIS.2013.7.1.24-48.

Istanto, Riza, and T. Triyanto. 'Religious Tolerance Through Stone Sculpture Production: The Case of Indonesian Sculptors'. Walisongo: Jurnal Penelitian Sosial Keagamaan 27, no. 1 (30 July 2019). https://doi.org/10.2158o/ws.27.1.3630.

Jainuri, A. Radikalisme dan terorisme: akar ideologi dan tuntutan aksi. Intrans Publishing, 2016.

Kartodirdjo, Sartono. Sejak Indische sampai Indonesia. Penerbit Buku Kompas, 2005.

Laisa, Emna. 'Islam Dan Radikalisme'. Islamuna: Jurnal Studi Islam 1, no. 1 (2 January 2014). https://doi.org/10.19105/islamuna.vii1.554. 
Liputan6.com. 'Perguruan Tinggi Terpapar Radikalisme'. liputan6.com, 5 June 2018. https://www.liputan6.com/news/read/3549087/perguruan-tinggi-terpaparradikalisme.

Ma'arif, Muhammad Anas. 'Internalisasi Nilai Multikulutural Dalam Mengembangkan Sikap Toleransi ( Studi Di Di Pesantren Mahasiswa Universitas Islam Malang)'. Nazhruna: Jurnal Pendidikan Islam 2, no. 1 (24 March 2019). https://doi.org/10.31538/nzh.v2i1.179.

Ma'arif, Syamsul. 'Ideologi Pesantren Salaf: Deradikalisasi Agama Dan Budaya Damai'. Ibda' 12, no. 2 (2014): 198-209.

Mahfud, Choirul, Niken Prasetyawati, Wahyuddin Wahyuddin, Zainul Muhibbin, Dyah Satya Yoga Agustin, and Heni Sukmawati. 'Religious Radicalism, Global Terrorism and Islamic Challenges in Contemporary Indonesia'. Jurnal Sosial Humaniora 11, no. 1 (27 July 2018): 8-18-18. https://doi.org/10.12962/j24433527.v11i1.3550.

Maulana, Dirga. 'The Exclusivism of Religion Teachers: Intolerance and Radicalism in Indonesian Public Schools'. Studia Islamika 24, no. 2 (31 August 2017): 395401. https://doi.org/10.15408/sdi.v24i2.5707.

Muchith, Muhammad Saekan. 'Radikalisme Dalam Dunia Pendidikan'. ADDIN 10, no. 1 (2016): 163-180.

Mumtahanah, Lusia. 'Integrasi Nilai Multikultural Dalam Pembelajaran Pendidikan Agama Islam Di Sekolah Dasar'. Nazhruna: Jurnal Pendidikan Islam 3, no. 1 (7 February 2020): 55-74. https://doi.org/10.31538/nzh.v3i1.461.

Naim, Ngainun. 'Pengembangan Pendidikan Aswaja Sebagai Strategi Deradikalisasi'. Walisongo: Jurnal Penelitian Sosial Keagamaan 23, no. 1 (15 June 2015): 69-88. https://doi.org/10.21580/ws.23.1.222.

Nashir, Haedar, Zuly Qodir, Achmad Nurmandi, Hasse Jubba, and Mega Hidayati. 'Muhammadiyah's Moderation Stance in the 2019 General Election: Critical Views from Within'. Al-Jami'ah: Journal of Islamic Studies 57, no. 1 (29 June 2019): 1-24. https://doi.org/10.14421/ajis.2019.571.1-24.

Nasution, Harun. Islam ditinjau dari berbagai aspeknya. Jilid II: ... Cet. 6. Jakarta: Penerbit Universitas Indonesia, 1986.

Raihani. Creating Multicultural Citizens: A Portrayal of Contemporary Indonesian Education, 2014 . http://search.ebscohost.com/login.aspx?direct=true\&scope=site\&db=nlebk\&d $\mathrm{b}=$ nlabk\&AN=664169.

Rosyad, Ali Miftakhu. "Al-Afkar, Journal for Islamic Studies URGENSI INOVASI PEMBELAJARAN DALAM PENDIDIKAN AGAMA ISLAM Al-Afkar, Journal for Islamic Studies THE URGENCY OF LEARNING INNOVATION ON ISLAMIC RELIGIOUS STUDY" 3, no. 1 (2019). https://doi.org/10.5281/zenodo.2546882.

_-_. "Implementasi Pendidikan Karakter Dalam Pembelajaran Pendidikan Agama Islam Di Sekolah Muhammadiyah Se-Kabupaten Indramayu. Al-Afkar.” Journal for Islamic Studies 4 (n.d.). 
Reid, Anthony. 'Religious Pluralism or Conformity in Southeast Asia's Cultural Legacy'. Studia Islamika 22, no. 3 (2015): 387-404. http://journal.uinjkt.ac.id/studia-islamika/article/view/2352.

Rubaidi, A. Radikalisme Islam, Nahdlatul Ulama E masa depan moderatisme Islam di Indonesia. Logung Pustaka, 2008.

Sabirin, Rahimi. Islam E radikalisme. Jakarta: Teras, 2004.

Subandi, Subandi, Ahmad Fauzan, Muhammad Muchsin Afriyadi, and Mispani Ramli. 'Implementation of Multicultural and Moderate Islamic Education at the Elementary Schools in Shaping the Nationalism'. Tadris: Jurnal Keguruan Dan Ilmu Tarbiyah 4, no. 2 (27 December 2019): 247-55. https://doi.org/10.24042/tadris.v4i2.5003.

Suharto, Toto. 'Gagasan Pendidikan Muhammadiyah dan NU sebagai Potret Pendidikan Islam Moderat di Indonesia'. Islamica: jurnal studi keislaman 9, no. 1 (23 September 2015): 81-109. https://doi.org/10.15642/islamica.2014.9.1.81109.

- - ' Indonesianisasi Islam: Penguatan Islam Moderat Dalam Lembaga Pendidikan Islam Di Indonesia'. Al-Tahrir: Jurnal Pemikiran Islam 17, no. 1 (24 May 2017): 155-78. https://doi.org/10.21154/altahrir.v17i1.803.

Syam, Nur. Tantangan Multikulturalisme Indonesia: Dari Radikalisme Menuju Kebangsaan. Yogyakarta, Indonesia: Penerbit Kanisius, 2009.

Thohir, Muhammad. 'Radikalisme Versus Pendidikan Agama Menggali Akar Radikalisme Dari Kekerasan Terhadap Anak Atas Nama Pendidikan Agama'. Nadwa 9, no. 2 (2015): 167-182.

Ummah, Sun c. 'Akar Radikalisme Islam Di Indonesia'. HUMANIKA 12, no. 1 (2012).

Wahid, Abdurrahman. Islamku Islam Anda Islam Kita: Agama Masyarakat Negara Demokrasi. Jakarta Pusat: The Wahid Institute, 2006. https://archive.org/details/abdurrahmanwahid-islamkuislamandaislamkitazoo6.

Woodward, Mark R., and Damardjati Supadjar. Islam Jawa: Kesalehan Normatif versus Kebatinan. Cet. 1. Yogyakarta: LKiS, 1999.

Zainiyati, Husniyatus Salamah. 'Curriculum, Islamic Understanding and Radical Islamic Movements in Indonesia'. Journal of Indonesian Islam 10, no. 2 (2016): 285-307. https://doi.org/10.15642/JIIS.2016.10.2.285-308. 